\title{
PEMETAAN KESIAPSIAGAAN RUMAH TANGGA DALAM MENGANTISIPASI BENCANA GEMPA BUMI PATAHAN LEMBANG
}

\author{
Yunarto, Yuliana Susilowati, Wawan Hendriawan Nur, Yugo Kumoro \\ Pusat Penelitian Geoteknologi, Lembaga Ilmu Pengetahuan Indonesia \\ Komplek LIPI, Jalan Sangkuriang Bandung, 40135, Indonesia \\ Email : yunarto@gmail.com
}

\begin{abstract}
Abstrak
Patahan Lembang terletak di utara Kota Bandung yang melintang dari timur ke barat dengan panjang $29 \mathrm{~km}$. Pengamatan geodetik membuktikan bahwa patahan Lembang adalah patahan aktif dan berpotensi memiliki risiko guncangan gempa besar. Banyak penduduk yang bermukim dan mencari penghidupan di wilayah sekitar patahan ini, yang mungkin dapat terdampak gempa dari patahan ini. Dalam upaya pengurangan risiko bencana di wilayah ini perlu kiranya memahami tingkat kesiapsiagaan rumah tangga, terutama yang berada di wilayah rawan bencana tersebut. Penelitian ini bertujuan untuk memetakan indeks kesiapsiagaan rumah tangga secara spasial dalam mengantisipasi bencana gempa bumi patahan lembang di Kabupaten Bandung Barat bagian Utara. Hasil survey di Kecamatan Lembang, Parongpon dan Ngamprah dengan menggunakan kuesioner tertutup, menunjukkan tingkat kesiapsiagaan rumah tangga di daerah kawasan patahan lembang dalam mengantisipasi gempa dikategorikan sudah hampir siap. Nilai indek kesiapsiagaan tertinggi terdapat di Kecamatan Lembang 61,38 \%, disusul dengan Kecamatan Parongpon 59,15\%, dan Kecamatan Ngamprah 55,66 \%.
\end{abstract}

Kata kunci : Patahan lembang, gempa, kesiapsiagaan

\begin{abstract}
Lembang fault is located in the north of Bandung City where crosses from east to west with a length $29 \mathrm{~km}$. The observation of Geodetic proves that Lembang fault is the active fault and potentially has big earthquake shock risk. Many people settling down and working in around this fault may be able to be affected by this fault. In order to decrease the risk of the earthquake in this area, it is necessary to understand the level of preparedness of the household, especially people being in those disaster-prone areas. This research aims to map the index of preparedness of the household specifically in anticipating earthquake disaster of Lembang fault in the northern area of West Bandung Region. The result of the survey in Lembang, Parongpon and Ngamprah Districts using closed questionnaire shows the level of preparedness of household in the region of Lembang fault in anticipating earthquake being categorized almost ready. The highest index value of preparedness is in Lembang District with 61,3\% followed by Parongpon District with 59,15\% and Ngamprah District with 55,66\%
\end{abstract}

Keyword: Lembang Fault, Earthquake, Preparedness.

\section{PENDAHULUAN}

Patahan Lembang merupakan retakan sepanjang $29 \mathrm{~km}$ melintang dari timur ke barat di utara Kota Bandung
(Daryono, 2016). Hasil kajian Badan Meterologi, Klimatologi dan Geofisika (BMKG) menunjukkan bahwa laju pergeseran patahan Lembang mencapai 
5,0 mm/tahun (BMKG, 2017). Pengamatan geodetik membuktikan bahwa patahan Lembang adalah patahan aktif (Meilano et al., 2012). Patahan ini pernah bergerak dalam 10.000 tahun terakhir (Keller \& Pinter, 1996 dalam Maipark, 2015). Gempa besar berkekuatan di atas 6 skala Richter belum pernah tercatat di kawasan patahan Lembang. Namun, gempa berkekuatan 3 skala richter terjadi pada tahun 1834, 1879, 1910, 2003, dan 2011 (Yulianto, 2012). Studi paleoseismologi menunjukkan bahwa antara 500-2000 tahun yang lalu, patahan Lembang menghasilkan gempa dengan Magnitudo 6.6-6.8 (Yulianto, 2011). Hasil studi ini menyimpulkan bahwa daerah Kabupaten Bandung Barat bagian utara khususnya sekitar patahan Lembang memiliki risiko guncangan gempa besar (Yulianto, 2011).

Gempa bumi merupakan fenomena alam yang sulit untuk diprediksi kapan, dimana, berapa besar kekuatannya, sehingga sering menimbulkan kejutan dan kepanikan di tengah masyarakat, bahkan

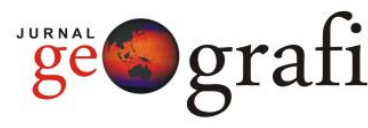

sering menimbulkan kerugian, baik jiwa maupun harta benda (Nagib, et al., 2007). Oleh karena itu apabila terjadi gempa dengan kekuatan di atas 5 skala Richter dapat menyebabkan terjadinya goncangan di permukaan bumi dan menggoyang benda-benda di atasnya seperti rumah/bangunan, perabotan rumah, tiang listrik, pohon dan sebagainya. Benda-benda yang tidak kuat menahan goncangan tersebut akan rubuh dan tumbang/jatuh, yang kemudian dapat menimpa orang yang berada dibawah atau didekatnya (Sungkawa, 2016). Gempa dengan kekuatan 3,4 SR pada 22 Juli 2011 dengan kedalaman $6 \mathrm{~km}$, berada pada jarak 12,5 km timur Lembang dan 16 $\mathrm{km}$ timur laut Bandung (Sulaeman dan Hidayati, 2011). BMKG menyebut kekuatan gempa yang bergerak di kawasan Bandung Utara pada 28 Agustus 2011 mencapai 3,3 skala Richter (M3.3) dengan kedalaman $6 \mathrm{~km}$. Gempa ini yang menimbulkan kerusakan 103 rumah (Gambar 1).

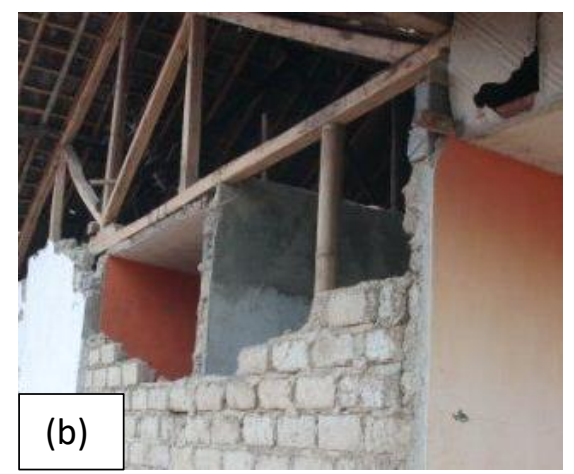

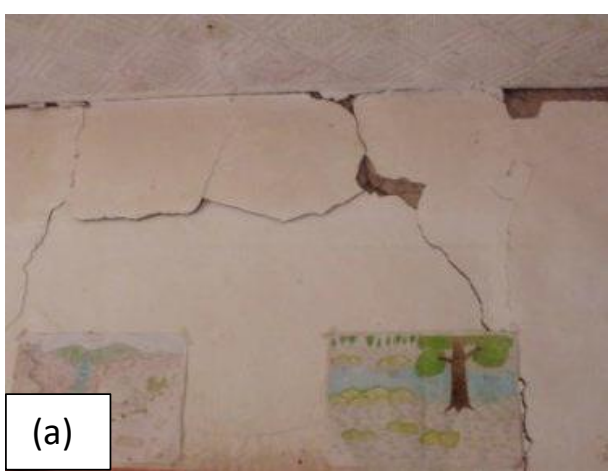

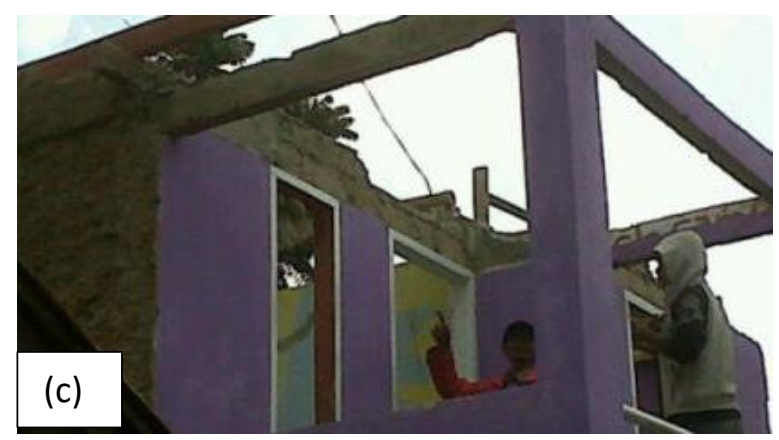

Gambar 1. (a) tembok retak, (b) tembok runtuh, (c) rumah rusak berat akibat gempa patahan Lembang 28 Agustus 2011 (Cisarua, Kabupaten Bandung Barat).

Sumber: https:// richocean.wordpress.com/2011/09/17/gempa-darat-ramadhan-28agustus-2011-3-3sr-cisarua-jawa-barat-bukti-sesar-lembang-aktif dan Pikiran Rakyat online 
Banyaknya korban jiwa dan harta benda ketika terjadi bencana alam, mencerminkan kurangnya kesiapan dan antisipasi masyarakat dalam menghadapi bencana alam. Hal ini berkaitan dengan minimnya pengetahuan dan informasi tentang fenomena alam yang menimbulkan bencana dan tingkat kerawanan setiap wilayah dalam menghadapi bencana (Nagib et al., 2007; Hidayati, et al., 2008). Dalam beberapa kasus bencana, hampir sebagian anggota masyarakat dengan kondisi kepanikannya tidak berinisiatif untuk menyelamatkan atau membantu korban. Selain itu beberapa anggota masyarakat berupaya membantu korban, tetapi karena ketidaktahuannya malah menambah beban korban. Oleh karena itu masyarakat perlu mendapatkan keterampilan teknikteknik sederhana tentang pertolongan pertama dan melakukan evakuasi korban (Hidayati, 2008). Dari pengalaman berbagai bencana alam tersebut, memberikan pelajaran yang berharga bagi masyarakat agar selalu waspada dan siaga dalam mengantipasi bencana (Nagib, et al., 2007).

Kesiapsiagaan merupakan upaya dan kegiatan yang dilakukan sebelum terjadi bencana alam untuk secara cepat dan efektif merespon keadaan/situasi pada saat dan setelah bencana. Upaya ini sangat diperlukan masyarakat untuk mengurangi risiko/dampak bencana alam, termasuk korban jiwa, kerugian harta benda, dan kerusakan lingkungan (Hidayati, 2008; Sutton dan Tierney, 2006). Menurut Undang-undang No. 24 tahun 2007, kesiapsiagaan adalah serangkaian kegiatan yang dilakukan untuk mengantisipasi bencana melalui pengorganisasian serta melalui langkah yang tepat guna dan berdaya guna.

Banyak penduduk yang bermukim dan mencari penghidupan di wilayah sekitar patahan Lembang, yang dapat terdampak gempa yang mungkin bersumber dari patahan ini. Dalam upaya pengurangan risiko bencana di wilayah di sekitar patahan Lembang tersebut perlu memahami tingkat kesiapsiagaan masyarakatnya yang berada di wilayah tersebut, terutama yang berada di wilayah rawan bencana gempa bumi. Rumah tangga merupakan salah satu pemangku kepentingan (stakeholder) kesiapsiagaan masyarakat yang menjadi ujung tombak, subjek dan objek dari kesiapsiagaan dan berpengaruh secara langsung terhadap risiko bencana maka kajian tingkat kesiapsiagaan rumah tangga menjadi penting (Hidayati, et al., 2011). Tujuan penelitian ini adalah memetakan indeks kesiapsiagaan rumah tangga secara spasial dalam mengantisipasi bencana gempa bumi patahan lembang di Kabupaten Bandung Barat bagian Utara. Indeks kesiapsiagaan ini akan digunakan untuk bahan evaluasi terhadap intervensi untuk meningkatkan ketahanan masyarakat, sehingga kemampuan rumah tangga dalam mengantisipasi bencana dapat ditingkatkan untuk mengurangi risiko bencana.

\section{METODE PENELITIAN}

Kajian tingkat kesiapsiagaan rumah tangga mengacu pada kerangka kerja (framework) yang dikembangkan LIPI bekerja sama dengan UNESCO/ISDR pada tahun 2006. Kerangka kerja kesiapsiagaan masyarakat digunakan sebagai alat untuk menilai seberapa jauh tingkat kesiapsiagaan masyarakat di suatu daerah (Hidayati, et al., 2006). Parameter yang menjadi acuan dalam kerangka kerja kesiapsiagaan menghadapi bencana gempabumi-tsunami, diantaranya pengetahuan dan sikap terhadap bencana; rencana tanggap darurat; sistem peringatan bencana; mobilisasi sumber daya (Hidayati, et al., 2006).

1. Pengetahuan merupakan faktor utama dan menjadi kunci untuk kesiapsiagaan. Pengetahuan yang dimiliki dapat mempengaruhi sikap dan kepedulian masyarakat untuk siap dan siaga dalam mengantisipasi bencana, terutama bagi masyarakat yang tinggal di daerah rentan terhadap bencana alam. 
2. Rencana tanggap darurat bencana merupakan rencana untuk merespon keadaan darurat bencana alam. Rencana ini bagian yang penting dalam kesiapsiagaan, terutama berkaitan dengan evakuasi, pertolongan dan penyelamatan, agar korban bencana dapat diminimalkan. Rencana yang berkaitan dengan evakuasi mencakup tempat-tempat evakuasi, peta dan jalur evakuasi, peralatan dan perlengkapan, latihan/simulasi dan penyelamatan dokumen-dokumen penting.

3. Sistem peringatan dini yang meliputi tanda peringatan dan distribusi informasi akan terjadinya bencana. Dengan adanya peringatan ini untuk mengurangi korban jiwa, harta benda dan kerusakan lingkungan.

4. Kemampuan memobilisasi sumber daya yang tersedia, baik sumber daya manusia (SDM), pendanaan dan sarana-prasarana penting untuk keadaan darurat. Kemampuan ini merupakan potensi yang dapat mendukung atau sebaliknya menjadi kendala dalam kesiapsiagaan bencana (Hidayati, 2008).

Kerangka kerja kesiapsiagaan masyarakat ini telah diuji di beberapa wilayah yang berpotensi terkena gempa bumi dan tsunami, yaitu di Kota Bengkulu pada tahun 2006, Kabupaten Padang Pariaman, Serang, Cilacap, dan Sikka tahun 2007 (Nagib, et al., 2007).

Dalam penelitian ini parameter kesiapsiagaan rumah tangga dalam mengantisipasi bencana gempa bumi, yaitu 1) pengetahuan dan sikap terhadap bencana; 2) rencana tanggap darurat; 3) mobilisasi sumber daya. Parameterparameter di atas tersebut diterjemahkan dalam bentuk variabel kesiapsiagaan masyarakat (Triyono et al., 2014). Berikut adalah variabel dari ketiga parameter di atas

Variabel parameter pengetahuan dan sikap terdiri dari:

- pengetahuan tentang bencana alam;

- pengetahuan tentang gempa bumi (penyebab gempa bumi, ciri-ciri gempa kuat, bencana yang diakibatkan gempa bumi).

- tindakan-tindakan yang harus dilakukan pada saat dan setelah terjadi gempa.

Dalam penelitian ini, tindakan yang harus dilakukan ketika terjadi gempa, umumnya tindakan yang berkaitan dengan responden berada di rumah ketika terjadi gempa, seperti berlindung di tempat aman, melindungi kepala, menjauhi bendabenda tergantung, menjauhi jendela/dinding kaca dan memungkinkan segera menuju lapangan terbuka. Tindakan ini tidak hanya di rumah, tetapi juga di dalam gedung, mobil atau kereta api dan tinggal di daerah pantai atau perbukitan ketika terjadi gempa bumi. Tindakan ini yang ditambahkan tersebut disesuaikan dengan buku saku tanggap tangkas tangguh menghadapi bencana dari BNPB tahun 2017.

Variabel berkaitan dengan rencana tanggap darurat terdiri dari :

- rencana tindakan yang harus dilakukan rumah tangga ketika terjadi bencana, seperti menyiapkan gambar dan poster jalur dan rambu-rambu evakuasi; menyepakati tempat pengungsian, menyiapkan P3K, menyiapkan tas siaga berisi dokumendokumen penting, menyiapkan pakaian dan makanan siap saji, menyiapkan nomor telpon fasilitasfasilitas penting untuk keadaan darurat (Rumah sakit/posko kesehatan, pemadam kebakaran, PDAM, Telkom, PLN, pelabuhan, bandara); latihan dan simulasi evakuasi.

- tindakan penyelamatan keluarga dari bencana, antara lain: menambah pengetahuan tentang gempa bumi, rencana pengungsian/evakuasi keluarga, melakukan simulasi evakuasi keluarga dan membangun rumah tahan gempa.

- tempat penyelamatan keluarga ketika terjadi bencana, antara lain rencana evakuasi, termasuk lokasi dan tempat 


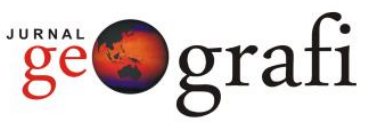

evakuasi, peta, tenda/posko bencana yang disediakan dan menuju lapangan terbuka yang aman.

Variabel yang berkaitan dengan memobilisasi sumber daya terdiri dari :

- keikutsertaan anggota rumah tangga dalam pelatihan dan seminar yang berkaitan dengan kesiapsiagaan dalam mengantisipasi bencana gempa. Seminar kebencanaan seperti jenis bencana, penyebab bencana dan tindakan yang harus dilakukan jika terjadi bencana akan memberikan tambahan pengetahuan anggota rumah tangga tentang kebencanaan berkaitan dengan kesiapsiagaan dalam menghadapi bencana. Pelatihanpelatihan berkaitan dengan kesiapsiagaan dalam menghadapi bencana seperti pertolongan pertama, evakuasi korban dan kepramukaan sangat diperlukan pada kondisi bencana. Pelatihan kesiapsiagaan memberikan bekal ilmu bermanfaat untuk menolong sesama ketika terjadi bencana.

- kesiapan dana yang dapat digunakan untuk kesiapsiagaan dalam mengantisipasi bencana, seperti tabungan, asuransi ataupun rumah di tempat lain. Informasi lain yang dijaring adalah kesediaan kerabat/famili/temen dekat yang mau membantu jika terjadi bencana.

Penilaian melalui indeks dilakukan untuk mengetahui tingkat kesiapsiagaan masyarakat menghadapi bencana alam, terutama gempa bumi di patahan Lembang. Indeks merupakan angka perbandingan yang dapat dibandingkan antara satu bilangan dengan bilangan lain yang berisi informasi tentang suatu kharakteristik tertentu pada waktu dan tempat yang sama atau berlainan (Hidayati, et al., 2008). Untuk menyederhakan dan memudahkan agar dimengerti, nilai indeks dikali seratus. Angka indeks dalam penelitian ini terdiri dari indeks tiap parameter, yaitu pengetahuan tentang bencana, rencana tanggap darurat, mobilsasi sumberdaya.

Kajian ini menggunakan angka indeks gabungan tidak ditimbang, artinya semua pertanyaan dalam parameter tersebut mempunyai bobot yang sama (masing-masing pertanyaan diberi nilai satu). Penentuan nilai indeks untuk setiap parameter dihitung berdasarkan rumus (Hidayati, et al., 2008):

Indeks $=($ jumlah skor riil parameter/skor maksimum parameter) $\times 100$.

Skor maksimum parameter diperoleh dari jumlah pertanyaan dalam parameter yang diindeks. Jika dalam satu pertanyaan terdapat sub-sub pertanyaan (misal a,b,c dan seterusnya), maka setiap sub pertanyaan tersebut diberi skor 1 dibagi jumlah sub pertanyaan. Total skor riil parameter diperoleh dengan menjumlahkan skor riil seluruh pertanyaan dalam parameter yang bersangkutan. Nilai indeks berada pada kisaran antara 0 - 100 (Tabel 1.), sehingga semakin tinggi nilai indeks, semakin tinggi pula tingkat kesiapsiagaannya (Hidayati et al., 2006). Setelah dihitung indeks parameter dari satu responden individu/rumah tangga kemudian dapat ditentukan nilai indeks keseluruhan sampel. Jika jumlah sampel adalah $n$, maka indeks keseluruhan sampel dapat dihitung dengan menjumlahkan indeks seluruh sampel dibagi dengan jumlah sampel (n).

Penilaian indeks kesiapsiagaan masyarakat dihitung dengan menggunakan formulasi sebagai berikut:

Indeks rumah tangga (RT)

$=0,50 \times$ indeks $\mathrm{P}+0,35 \times$ indeks RTD +

$0,15 \mathrm{x}$ indeks MSD

dimana :

$\mathrm{P}$ : pengetahuan

RTD : rencana tanggap darurat

MSD : mobilisasi sumber daya

(modifikasi formulasi Hidayati, et al., 2008). 
Tabel 1. Katagori Nilai Indeks Kesiapsiagaan Rumah Tangga

\begin{tabular}{ccl} 
No & Nilai Indeks & \multicolumn{1}{c}{ Kategori } \\
\hline 1. & $80-100$ & Sangat siap \\
\hline 2. & $65-79$ & Siap \\
\hline 3. & $55-64$ & Hampir siap \\
\hline 4. & $40-54$ & Kurang siap \\
\hline 5. & $<40$ & Belum siap \\
\hline
\end{tabular}

Sumber : Kajian Kesiapsiagaan masyarakat dalam mengantisipasi bencana alam (2007)

Penelitian tentang kesiapsiagaan masyarakat dalam mengantisipasi bencana gempa bumi dilakukan di Kabupaten Bandung Barat, menggunakan kombinasi pendekatan kuantitatif dan kualitatif. Pendekatan kuantitatif dilakukan dengan survei terhadap masyarakat dengan menggunakan kuesioner tertutup. Sedangkan pendekatan kualitatif dilakukan dengan wawancara dengan aparat pemerintahan setempat (kepala desa) untuk mendapat gambaran atau informasi tentang kesiapsiagaan rumah tangga dalam mengantisipasi bencana gempa bumi.

\section{Data yang Digunakan}

Dalam penelitian ini, data yang digunakan adalah data spasial dan data tabulasi.

Data spasial terdiri dari :

- citra SRTM 30m dari DLR Jerman tahun 2005,

- peta titik gempa pada tanggal 22 Juli 2011 (M3,3) dan 28 Agustus 2011 (M3,4).

- peta raster patahan Lembang (Meilano, et al., 2012) yang sudah dikoreksi geometrik.

- peta topografi skala 1 : 25.000 dari Badan Informasi Geospasial.

- peta wilayah administrasi Kecamatan skala 1 : 25.000 dari Badan Informasi Geospasial.

- peta geologi lembar Bandung skala 1 : 100.000 dari Pusat Survei Geologi Badan Geologi (Silitonga, 1973).

Sedangkan data tabulasi: kependudukan dari BPS Kabupaten Bandung Barat tahun 2017.

\section{Pemilihan Lokasi Kajian}

Berkaitan dengan potensi gempa bumi di Patahan Lembang, pemilihan lokasi dilakukan secara purposif berdasarkan pertimbangan kerentanan wilayah dan masyarakat (Hidayati, et al., 2008) di Kabupaten Bandung Barat bagian utara. Penelitian ini difokuskan di Kecamatan Lembang, Parongpong dan Ngamprah. Ketiga kecamatan ini secara geografis dan geologis termasuk wilayah yang berada atau dekat dengan patahan lembang, termasuk yang rentan terhadap gempa bumi. Banyak penduduk yang tinggal di daerah kecamatan tersebut, bahkan ada yang tinggal di jalur patahan Lembang. Kriteria pemilihan lokasi yang menjadi pusat survei diantaranya (1) jumlah dan kepadatan penduduk; (2) jarak lokasi dengan potensi gempa (Hidayati, et al., 2008).

Berdasarkan data BPS Kabupaten Bandung Barat tahun 2017, Kecamatan Lembang mempunyai jumlah penduduk sebanyak 194.540 jiwa dengan kepadatan penduduk 2.036 jiwa/ $\mathrm{Km}^{2}$. Sementara Kecamatan Parongpong mempunya jumlah penduduk 111.590 jiwa dengan kepadatan penduduk 2.478 jiwa/ $/ \mathrm{Km}^{2}$ dan Kecamatan Ngamprah berpenduduk 174.872 jiwa dengan kepadatan penduduk 4.857 jiwa/ $\mathrm{Km}^{2}$. Kecamatan Lembang berada pada ketinggian antara 1.312 hingga 2.084 meter di atas permukaan laut. Kecamatan ini merupakan daerah tujuan wisata seperti Maribaya dan Gunung Tangkuban Perahu, yang dikunjungi masyarakat domestik maupun mancanegara. Kecamatan Parongpong terkenal dengan wisata 


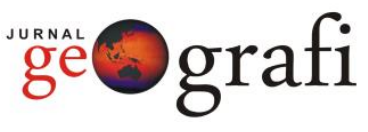

bunga, karena mayoritas petani di wilayah ini merupakan petani bunga dan tanaman hias lainnya, sehingga banyak masyarakat yang datang baik dari dalam ataupun dari wilayah lain. Kecamatan Ngamprah merupakan Kota Kabupaten Bandung Barat yang dekat dengan pusat pemerintahan, yang tentunya banyak masyarakat yang ditinggal di Wilayah ini. Jika dilihat dari lokasi, Kecamatan Lembang dan Parongpong yang berada di jalur patahan dan Kecamatan Ngamprah tidak jauh dari patahan lembang.

Survei dilakukan terhadap 109 responden rumah tangga/individu yang terdiri dari Kecamatan Lembang 33 responden, Parongpong 39 respon, Ngamprah 29 responden dan 8 responden aparat desa. Pemilihan responden di lokasi tersebut dilakukan secara acak dan insidental. Semakin dekat lokasi dengan Patahan Lembang, risiko terhadap gempa patahan lembang semakin besar. Selain itu dilakukan wawancara terbuka dengan beberapa aparat desa (Kepala Desa) untuk mendapat masukan kondisi masyarakatnya dalam menghadapi bencana.

Penentuan peta indeks kesiapsiagaan rumah tangga dengan menggunakan sistem informasi geografis, dimulai dengan deliniasi patahan lembang dari peta citra STRM 30m yang dioverlay dengan peta geologi, peta topografi (kontur) dan peta raster patahan lembang. Kemudian analisis union peta patahan Lembang dengan peta titik-titik gempa, dihasilkan peta titik gempa di lokasi patahan Lembang. Kedua peta, yaitu peta penduduk per Kecamatan dan peta titik gempa patahan Lembang dianalisis union untuk menghasilkan peta penduduk per Kecamatan yang berada di daerah patahan Lembang. Kemudian penyebaran kuesioner kesiapsiagaan rumah tangga di Kecamatan yang berada di jalur patahan ataupun yang dekat dengan patahan. Hasil survei diolah dan dianalisis dengan menggunakan EXCEL untuk menghitung indeks pangetahuan, indeks rencana tanggap darurat dan indeks mobilisasi sumber daya. Ketiga indeks tersebut dihitung dengan menggunakan formula indeks kesiapasigaan rumah tangga untuk pembentukan peta indeks kesiapsiagaan rumah tangga (Gambar 2).

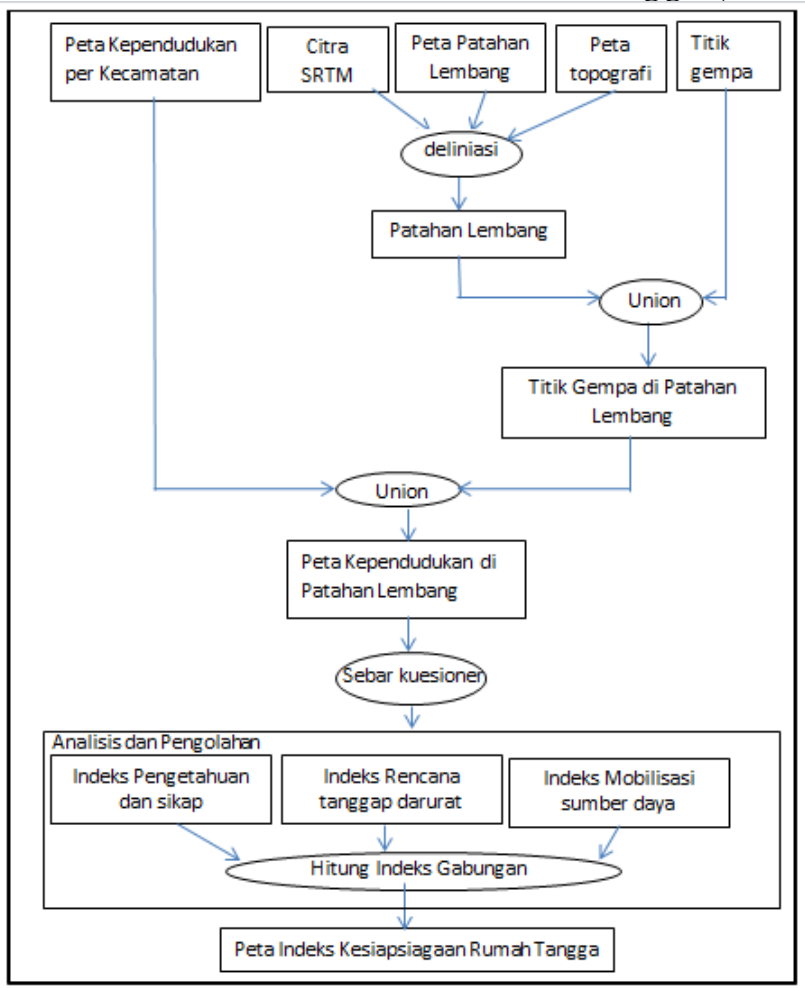

Gambar 2. Diagram Alir Penentuan Peta Indeks Kesiapsiagaan Rumah Tangga/Individu 
HASIL DAN PEMBAHASAN Pengetahuan Kebencanaan

Parameter pengetahuan merupakan pendukung tingkat kesiapsiagaan rumah tangga di lokasi kajian. Secara umum pengetahuan rumah tangga dalam mengantisipasi bencana gempa bumi di lokasi kajian, dikategorikan sudah hampir siap. Hal ini tercermin dari skor pengetahuan rumah tangga yang mencapai 62,32. Bila dirinci menurut zona tempat tinggal, pengetahuan rumah tangga di Kecamatan Lembang dan Parongpong sudah mencapai jenjang siap, kecuali di Kecamatan Ngamprah yang dikategori hampir siap. Kesiapan pengetahuan di kecamatan Lembang dan Parongpong ditunjukkan skor masingmasing mencapai 65,35 dan 65,10, sedangkan Ngamprah hanya 56 (Gambar 3).

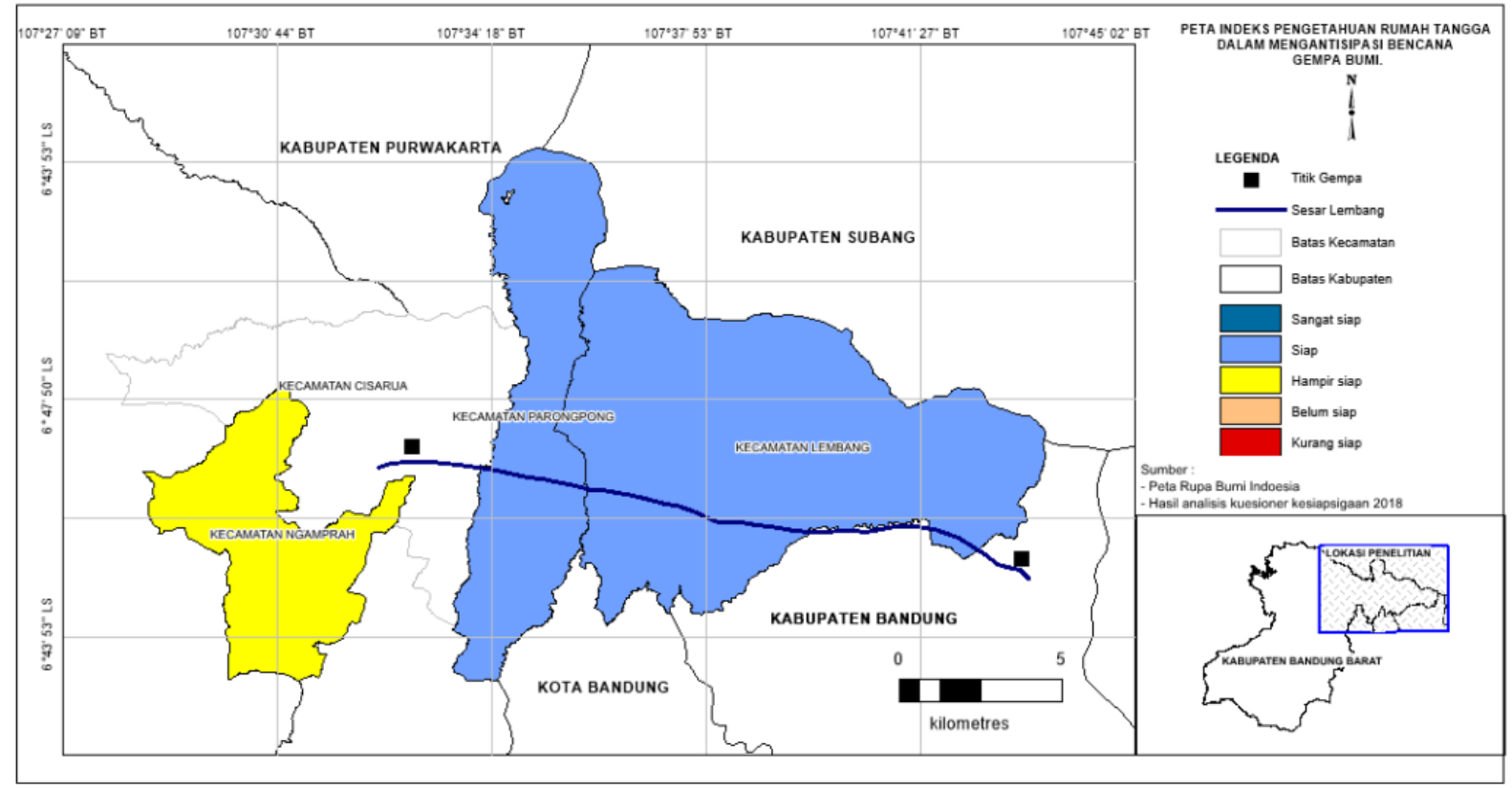

Gambar 3. Peta Indeks Pengetahuan Rumah Tangga Dalam Mengantisipasi Bencana Gempa Bumi

Tingkat kesiapsiagaan pengetahuan dan sikap rumah tangga di atas dapat diukur dengan beberapa indikator yang relevan, diantaranya indikator penyebab terjadinya gempa bumi, indikator sumber informasi terjadinya gempa, indikator pernah mendengar bahwa daerahnya rawan gempa dan indikator sumber informasi bahwa daerahnya rawan gempa.

\section{Indikator Penyebab Terjadinya Gempa Bumi}

Secara umum pengetahuan rumah tangga tentang penyebab terjadinya gempa bumi relatif cukup baik. Hal ini tercermin dari persentase jawaban responden, yaitu memilih gunung meletus sebanyak $73 \%$, pergeseran kerak bumi sebesar $71 \%$, hantaman benda langit 39\% dan ledakan nuklir 37\% (Gambar 4). Hasil survei di lokasi kajian (Gambar 3) menunjukkan bahwa pengetahuan responden tentang penyebab gempa, sebagian besar responden di Kecamatan Lembang dan Parongpong memilih bahwa gunung meletus merupakan penyebab gempa bumi masing-masing sebanyak 79\%, sedangkan di Kecamatan Ngamprah hanya 59\%. Hal ini menunjukkan responden Kecamatan Lembang dan Parongpong yang berada dekat dengan gunung Tangkuban Perahu cukup paham dibandingkan dengan responden Kecamatan Ngamprah yang agak jauh dari gunung tersebut. Responden Kecamatan Lembang dan Parongpong meyakini bahwa tiap gunung 
api sebelum mengalami erupsi akan didahului dengan gempa-gempa kecil atau besar. Adapun responden menjawab pergesaran kerak bumi penyebab gempa bumi, sebagian besar responden Kecamatan Parongpong dan Ngamprah sebanyak $77 \%$ dan $76 \%$, sedangkan Kecamatan Lembang hanya $61 \%$.

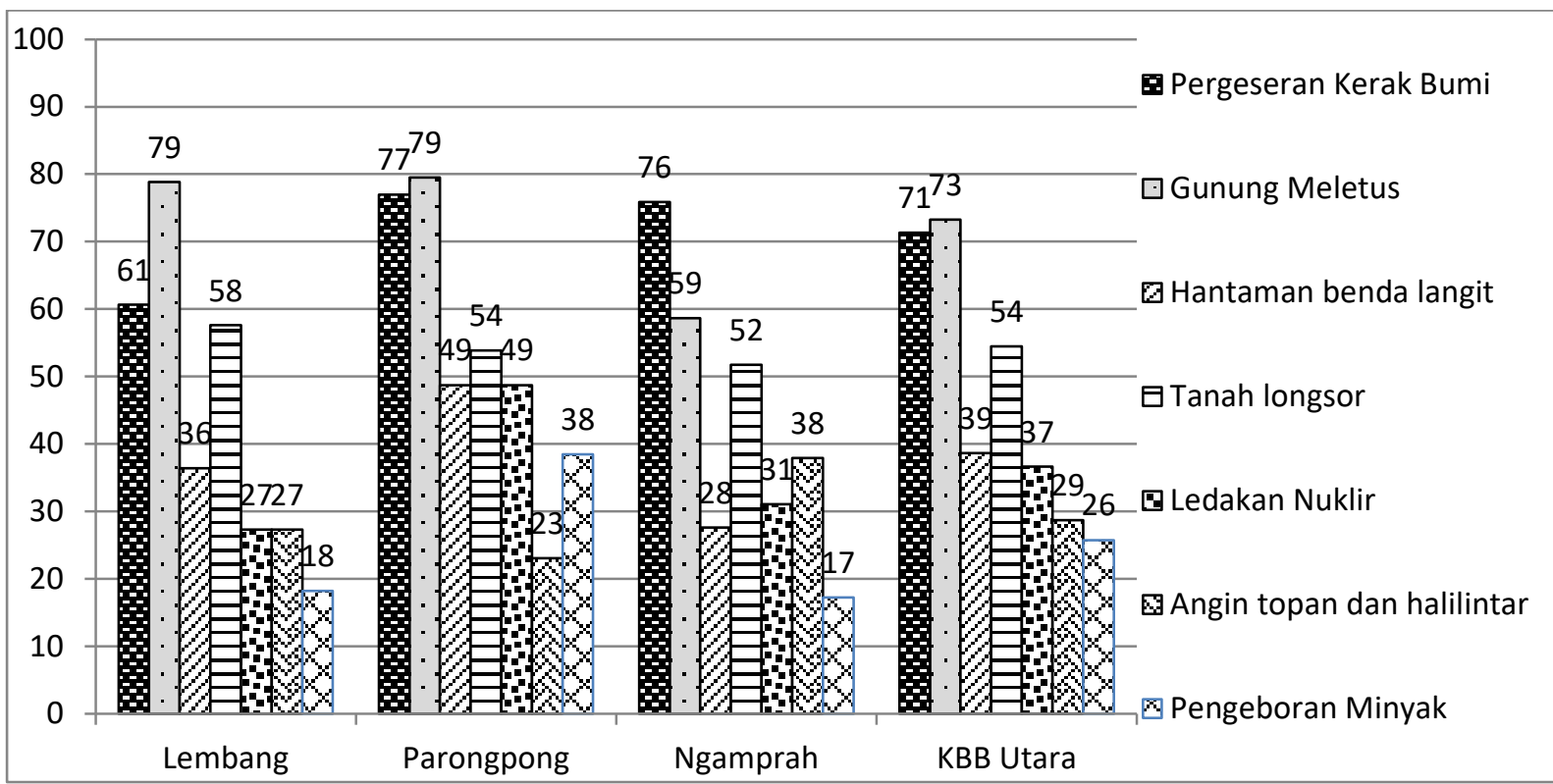

Gambar 4. Persentase Rumah Tangga Tentang Penyebab Terjadi Bencana Gempa Bumi

Sumber: Kajian Kesiapsiagaan masyarakat dalam mengantisipasi bencana alam (2006)

Dari kedua jawaban yang benar tersebut menunjukkan bahwa responden di Kecamatan Parongpong lebih memahami tentang penyebab gempa bumi dibandingkan dengan responden di kecamatan lainnya. Responden di Kecamatan Parongpong menduga bahwa penyebab gempa bumi selain berasal dari gunung meletus dapat pula dari pergeseran kerak bumi.

Selain disediakan jawaban yang benar mengenai kejadian alam yang menyebabkan gempa bumi, responden juga diberikan jawaban yang sebenarnya bukan jawaban yang tepat, yaitu tanah longsor, angin topan dan halilintar dan pemboran minyak. Hasil kajian mengungkapkan bahwa pada umumnya responden belum mengetahui bahwa jawaban tersebut tidak benar. Persentase jawaban responden yang kurang tepat tersebut masih cukup tinggi. Hal ini ditunjukkan dengan jawaban "ya" pada alternatif jawaban tersebut, seperti tanah longsor $54 \%$, angin topan dan halilintar $29 \%$ dan pengeboran minyak $26 \%$.

\section{Indikator Sumber Informasi Gempa}

Pengetahuan rumah tangga tentang gempa bumi umumnya diperoleh dari media elektronik, saudara, kerabat, teman dan tetangga, radio, media cetak, LSM dan seminar. Informasi terbanyak dari TV (95\%), disusul informasi dari saudara, kerabat, teman dan tetangga $(77 \%)$ dan media cetak (71\%), radio (69\%), petugas pemerintah (64\%), LSM dan lembaga non pemerintah (43\%), sosialisasi, seminar dan pertemuan $(40 \%)$, dan buku, poster, leaflet, rambu peringatan hanya $20 \%$. Media elektronik (TV dan radio) sering memberitakan kejadian bencana gempa atau tsunami di Aceh (2004), Pangandaran (2007), gempa Yogya (2006), gempa Tasikmalaya (2017), gempa Lebak (2018) dan daerah bencana lainnya.

Bila dirinci berdasarkan lokasi kajian, informasi kebencanaan melalui sosialisasi, seminar dan pertemuan $(40 \%)$ belum merata di tiap kecamatan. Hal ini ditunjukan dengan presentase jawaban responden di Kecamatan Parongpong 
$56 \%$, Ngamprah 38\% dan Lembang hanya $21 \%$.

\section{Indikator Daerahnya Rawan Gempa}

Berkaitan dengan lokasi kajian yang dekat dengan sumber gempa patahan Lembang, salah satu pertanyaan yang cukup penting untuk mengukur pengetahuan rumah tangga yang berkaitan dengan lingkungan tempat tinggalnya. Pertanyaan yang berkaitan dengan pengetahuan tentang gempa bumi adalah "apakah responden pernah mendengar bahwa di daerahnya rawan gempa?". Hampir sebagian rumah tangga/individu di Kecamatan Lembang mengetahuinya atau menjawab "ya" (60,61\%). Sementara di Kecamatan Parongpong dan Kecamatan Ngamprah, responden pernah mendengar daerahnya rawan gempa di bawah 50\%, yaitu 43,59\% dan 20,69\% (Gambar 5). Hal ini menunjukkan bahwa lokasi makin dekat dengan sumber potensi gempa maka akan semakin paham, artinya rumah tangga Kecamatan Lembang lebih paham akan daerahnya terhadap bencana dibandingkan Kecamatan lainnya. Hasil wawancara dengan Sekretaris Desa Ngamprah dan Kepala Desa Cilame, Kecamatan Ngamprah kaitannya dengan patahan Lembang. Mereka menyatakan hal yang sama, bahwa umumnya masyarakat pernah mendengar patahan Lembang, namun belum banyak informasi lebih jauh tentang patahan ini. Menurut salah satu warga masyarakat desa Langensari Kecamatan Lembang, belum mengetahui atau mendengar patahan lembang. Gempa yang dirasakan umumnya berasal dari wilayah lain, seperti gempa Tasikmalaya (2017) dan Lebak (2018) yang bersumber dari laut yang mengguncang Pulau Jawa.

\section{Indikator Sumber Informasi Daerahnya Rawan Gempa}

Bila dirinci berdasarkan lokasi kajian, persentase rumah tangga yang mendapat informasi tentang daerah rawan gempa di wilayahnya, melalui TV, di Kecamatan Lembang dan Ngamprah sebanyak 83$85 \%$ sedangkan di Parongpong hanya sebanyak $53 \%$. Responden yang mendapat informasi tersebut melalui radio di Kecamatan Lembang dan Ngamprah sebanyak 80-83\%, di Parongpong hanya sebanyak 59\%. Responden yang mendapat informasi tersebut melalui pemerintah kabupaten/desa di Kecamatan Lembang sebanyak $75 \%$, di Parongpon sebanyak $65 \%$, di Ngamprah sebanyak 83\%. Responden yang mendapat informasi tersebut melalui tokoh masyarakat di Kecamatan Lembang, Parongpong dan Ngamprah masing sebanyak $70 \%, 65 \%$ dan $85 \%$, sedangkan dari sumber informasi lainnya di bawah $51 \%$, kecuali Kecamatan Ngamprah sebanyak $67 \%$.

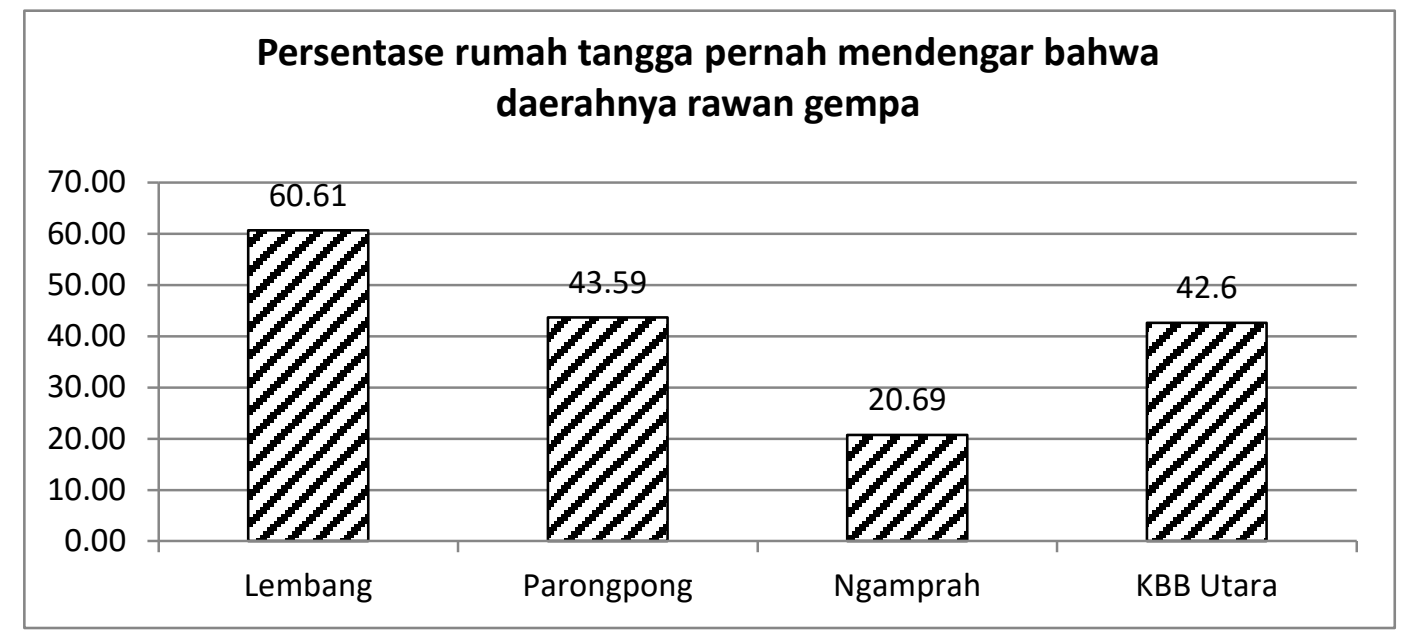

Gambar 5. Persentase Rumah Tangga yang Pernah Mendengar Daerahnya Rawan Gempa Bumi 


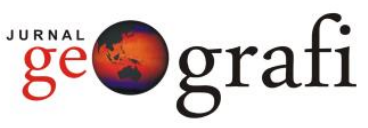

\section{Rencana Tanggap Darurat}

Rencana tanggap darurat atau penyelamatan keluarga merupakan hal yang perlu dilakukan untuk menghadapi bencana seperti gempa bumi (Hidayati, et al., 2006). Pengetahuan tentang kebencanaan yang dimiliki rumah tangga yang kemudian didukung oleh rencana tanggap darurat yang cukup memadai, akan lebih siapsiaga dalam mengantisipasi bencana (Hidayati, et al., 2006). Tingkat pengetahuan anggota rumah tangga tentang kebencanaan dikategorikan hampir siap, diikuti pula

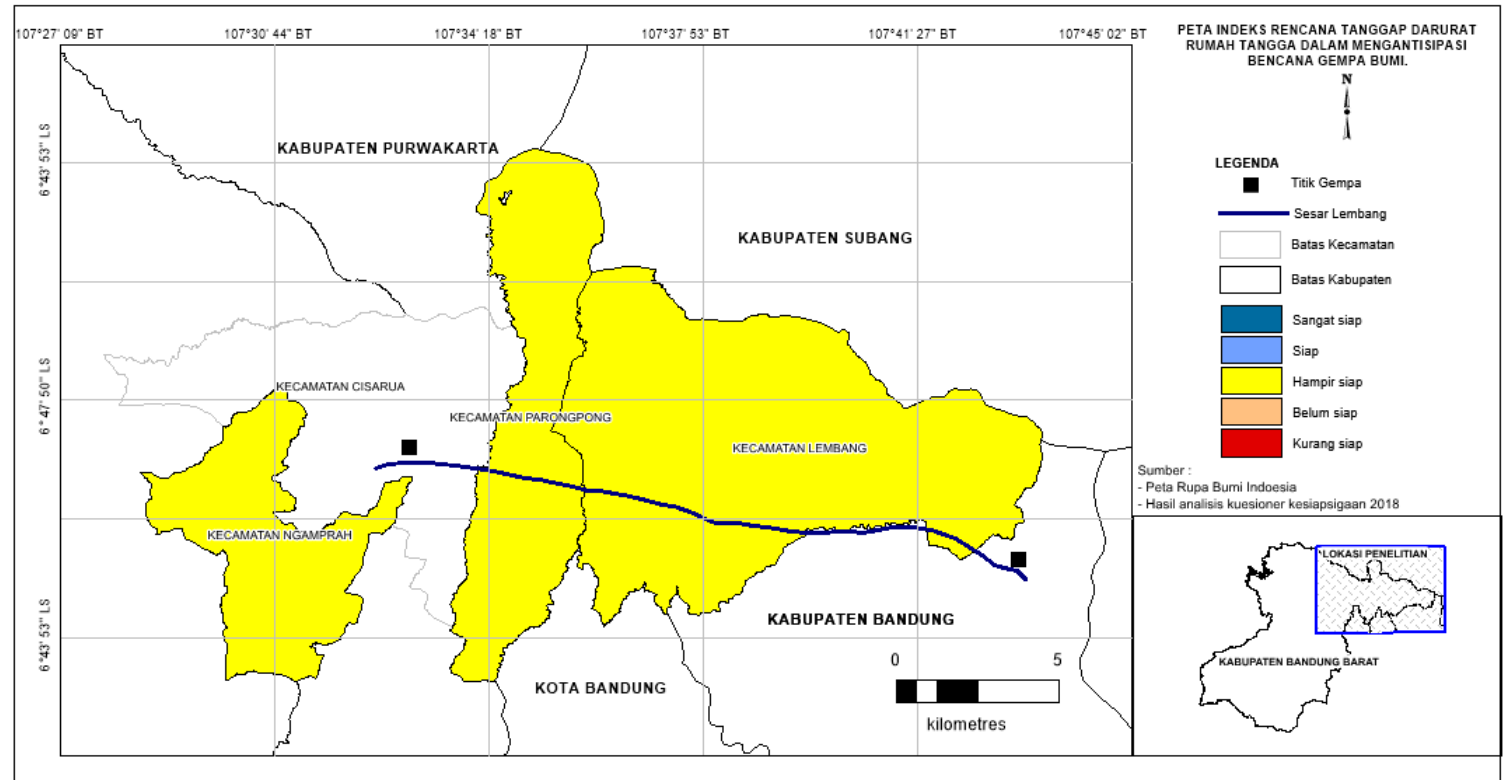

Gambar 6. Indeks Rencana Tanggap Darurat Rumah Tangga Dalam Mengantisipasi Bencana Gempa bumi

Kehampirsiapan rencana tanggap darurat dalam mengantisipasi bencana dapat diukur dengan beberapa indikator, diantaranya indikator tindakan penyelamatan keluarga dan indikator tempat penyelamatan.

\section{Indikator Tindakan Penyelamatkan Keluarga}

Gambar 7 mengukur secara rinci rencana tanggap darurat rumah tangga di lokasi kajian. Tindakan yang harus dilakukan rumah tangga ketika terjadi bencana di lokasi kajian, umumnya menyatakan akan menyiapkan gambar dan poster tindakan yang harus dilakukan dengan tindakan untuk meningkatkan kesiapsiagaan rumah tangga dalam menghadapi bencana dikategorikan hampir siap. Hal ini ditunjukkan dengan skor rencana tanggap darurat rumah tangga telah mencapai 60,43. Bila dirinci menurut zona tempat tinggal, skor rencana tanggap darurat rumah tangga tidak memiliki perbedaan yang mencolok baik di Kecamatan Ngamprah (61,40), Lembang, $(60,52)$ dan Parongpong 59,63, yang dikategori hampir siap (Gambar 6). 


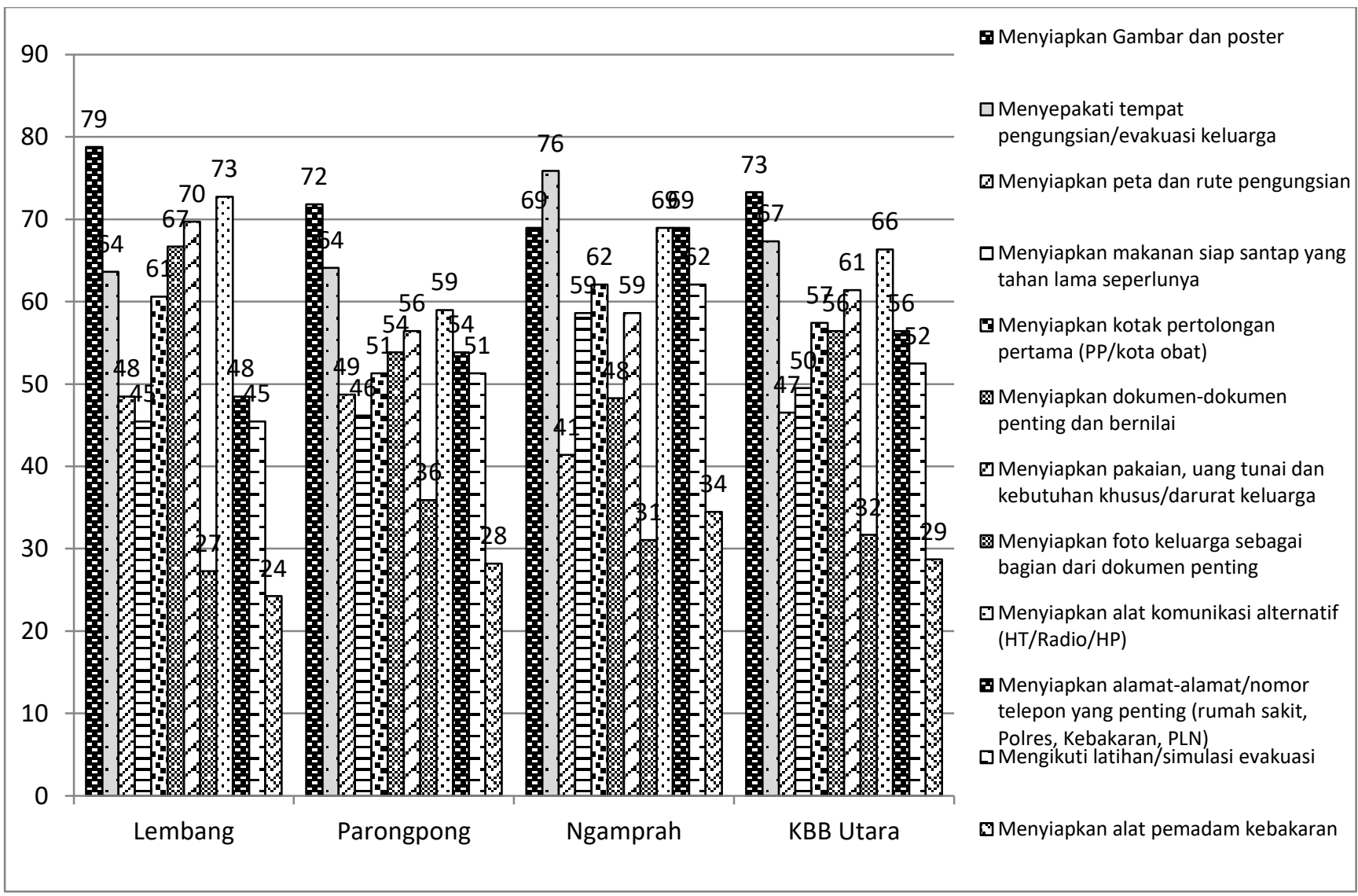

Gambar 7. Persentase Rumah Tangga Tentang Tindakan Penyelamatan Keluarga

Sumber : Kajian Kesiapsiagaan masyarakat dalam mengantisipasi bencana alam (2006)

Bila dikaji menurut jarak dari sumber gempa, Kecamatan Lembang yang paling banyak menyatakan akan menyiapkan gambar dan poster tindakan yang harus dilakukan $(79 \%)$ jika terjadi gempa dibandingkan dengan kecamatan lain. Hal menunjukkan tindakan yang di lakukan di Kecamatan Lembang sudah tepat. Hal ini dapat dimengerti karena kecamatan Lembang yang merupakan daerah yang dekat sumber gempa dan paham akan risiko yang ditimbulkannya. Adapun Kecamatan Ngamprah paling banyak menyepakati tempat pengungsian meskipun lokasi tidak jauh dari sumber gempa.

\section{Indikator Penyelamatan Keluarga}

Rencana tanggap darurat berkaitannya dengan tindakan untuk penyelamatan keluarga dikategorikan cukup siap. Hasil kajian menunjukkan sangat siap untuk menambah pengetahuan tentang gempa $(81,2 \%)$ dan membuat rencana pengungsian (70,3\%), dan cukup siap untuk melakukan latihan simulasi evakuasi keluarga (56,4\%) dan membangun rumah tahan gempa masih belum siap (30,7 \%). Belum siapnya membangun rumah tahan gempa, karena keterbatasan pengetahuan rumah tahan gempa yang dimiliki rumah tangga dan biaya. Adapun rumah tangga yang merencanakan untuk pindah rumah ke daerah yang lebih tinggi masih banyak $(43,6 \%)$. Hal ini menunjukkan responden belum dapat memahami bahwa tinggal di daerah yang lebih tinggi berisiko terkena longsor yang dipicu oleh gempa.

Bila dikaji menurut jarak dari sumber gempa, rumah tangga yang tinggal di Kecamatan Ngamprah dan Lembang cenderung lebih siap untuk menambah pengetahuan tentang gempa dibandingkan dengan Kecamatan Parongong. Bila rumah tangga ditanya membuat rencana pengungsian, Kecamatan Parongpong lebih siap 


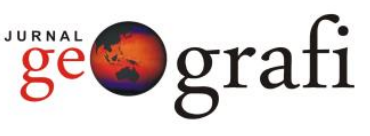

dibandingkan dengan Kecamatan Lembang dan Ngamprah. Seharusnya Kecamatan Lembang yang dekat dengan sumber gempa lebih siap dibandingkan dengan Kecamatan lainnya. Adapun ditanya rencana pindah ke daerah yang lebih tinggi, rumah tangga yang tinggal di Kecamatan Ngamprah cukup paham risikonya dibandingkan dengan kecamatan lain.

Rencana tanggap darurat berkaitannya dengan tindakan untuk tempat penyelamatan keluarga dikategorikan sudah siap. Hasil kajian menunjukkan sebagian rumah tangga akan menuju lapangan terbuka yang aman $(84,2 \%)$, posko bencana yang disediakan $(80,2 \%)$ bangunan evakuasi yang disediakan oleh BPBD/Pemerintah $(80,2)$ dan rumah saudara atau teman yang dekat yang aman $(74,6 \%)$. Hasil

dikaji menurut jarak dari sumber gempa, rencana penentuan tempat penyelamatan keluarga di Kecamatan Lembang dan Ngamprah cenderung lebih siap dibandingkan di Kecamatan Parongpong.

\section{Kemampuan Mobilisasi Sumber Daya}

Kehampirsiapsiagaan rumah tangga juga ditunjang oleh kurangnya upaya mobilisasi sumber daya yang dimiliki oleh rumah tangga di semua lokasi kajian. Hal ini tercermin dengan kesiapsiagaan parameter ini yang belum siap, yaitu skor 43,01 dan berada pada tingkatan paling rendah. Bila dirinci menurut zona tempat tinggal, skor mobilisasi sumber daya rumah tangga di Kecamatan Lembang $(50,18)$ dan Ngamprah $(41,32)$, dikategorikan belum siap, sedangkan Parongpong $(38,21)$ dikategori kurang siap (Gambar 8).

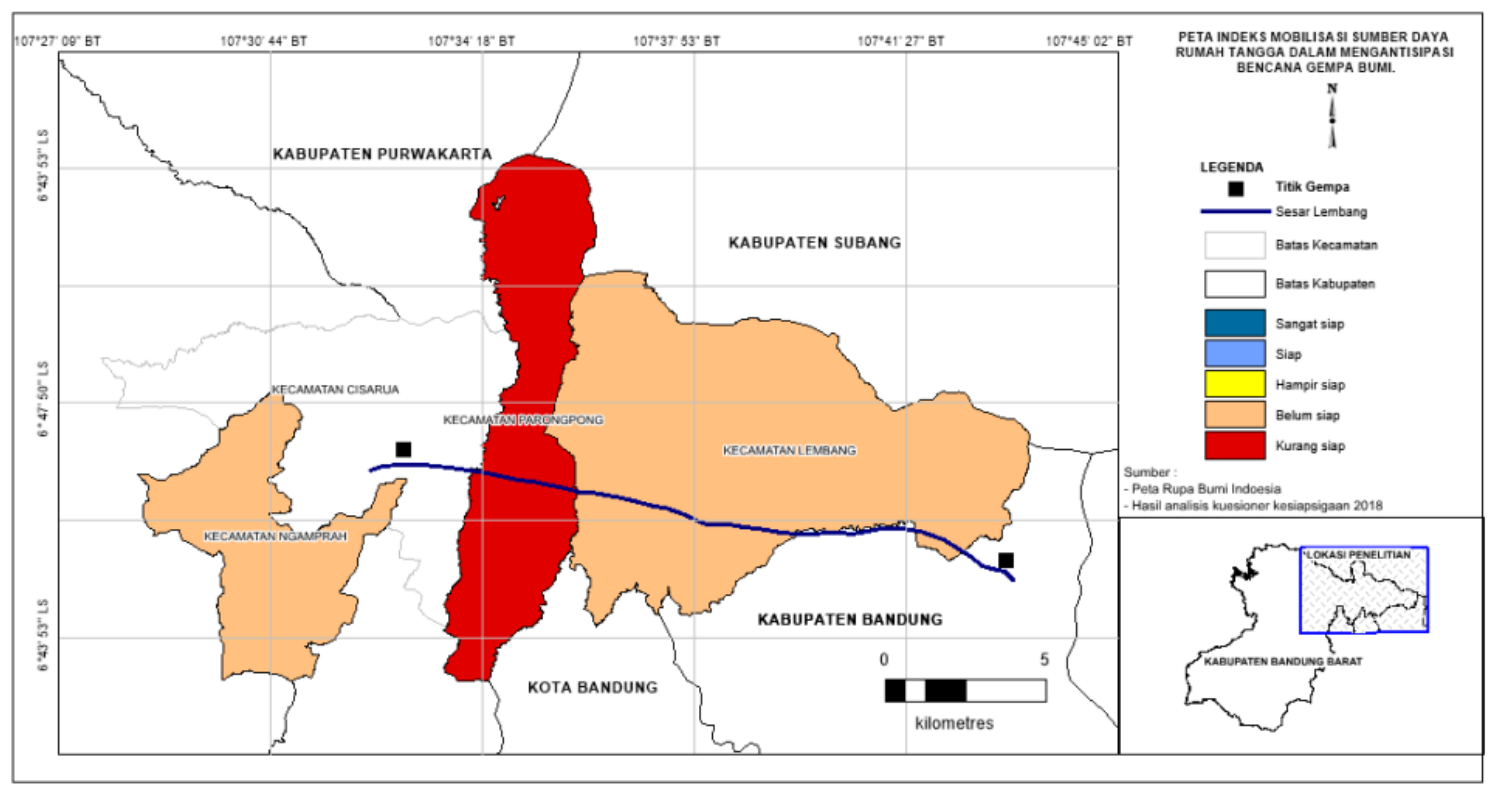

Gambar 8. Peta Indeks Mobilisasi Sumber Daya Rumah Tangga Dalam Mengantisipasi Bencana Gempa Bumi

Secara umum rumah tangga belum meningkatkan keterampilan untuk keadaan darurat bencana. Hal ini tercermin dari minimnya keikutsertaan anggota keluarga pada kegiatan pertemuan atau pelatihan yang berkaitan dengan kesiapsiagaan, pertolongan pertama dan evakuasi korban, pengolahan air bersih dan pengolahan makanan untuk keadaan darurat. Selain itu kebanyakan rumah tangga juga belum melakukan investasi untuk kewaspadaan keluarga, seperti tabungan, asuransi jiwa/harta/benda, dan tanah/rumah di tempat lain yang relatif aman dari bencana. Hal ini bertalian dengan kondisi ekonomi rumah tangga, kebanyakan 
belum mampu untuk melakukan investasi tersebut.

Hasil survei terhadap 101 rumah tangga, menunjukkan bahwa persentase rumah tangga yang ikut pelatihan dan seminar yang berkaitan dengan kesiapsiagaan dalam mengantisipasi bencana gempa hanya 34,7\% (Gambar 9).

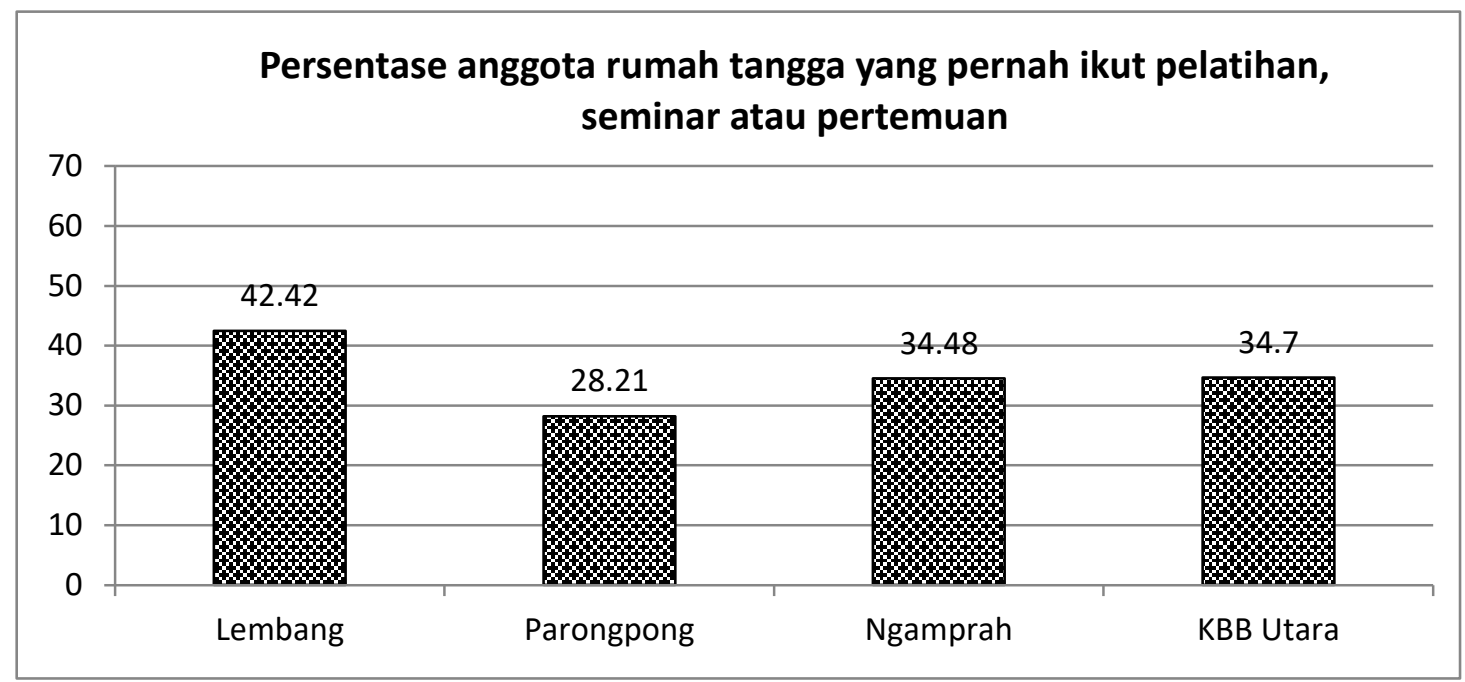

Gambar 9. Anggota Rumah Tangga yang Ikut Seminar, Pelatihan dan Pertemuan Kaitan dengan Kesiapsiagaan Dalam Menghadapi Bencana

Sumber : Kajian Kesiapsiagaan masyarakat dalam mengantisipasi bencana alam (2006)

Adapun responden yang pernah mengikuti pelatihan pertolongan pertama hanya diikuti 33\%, evakuasi korban 32\%, kepramukaan $30 \%$, pengolahan air bersih
(27\%) dan pengolahan makanan $27 \%$ (Gambar 10).

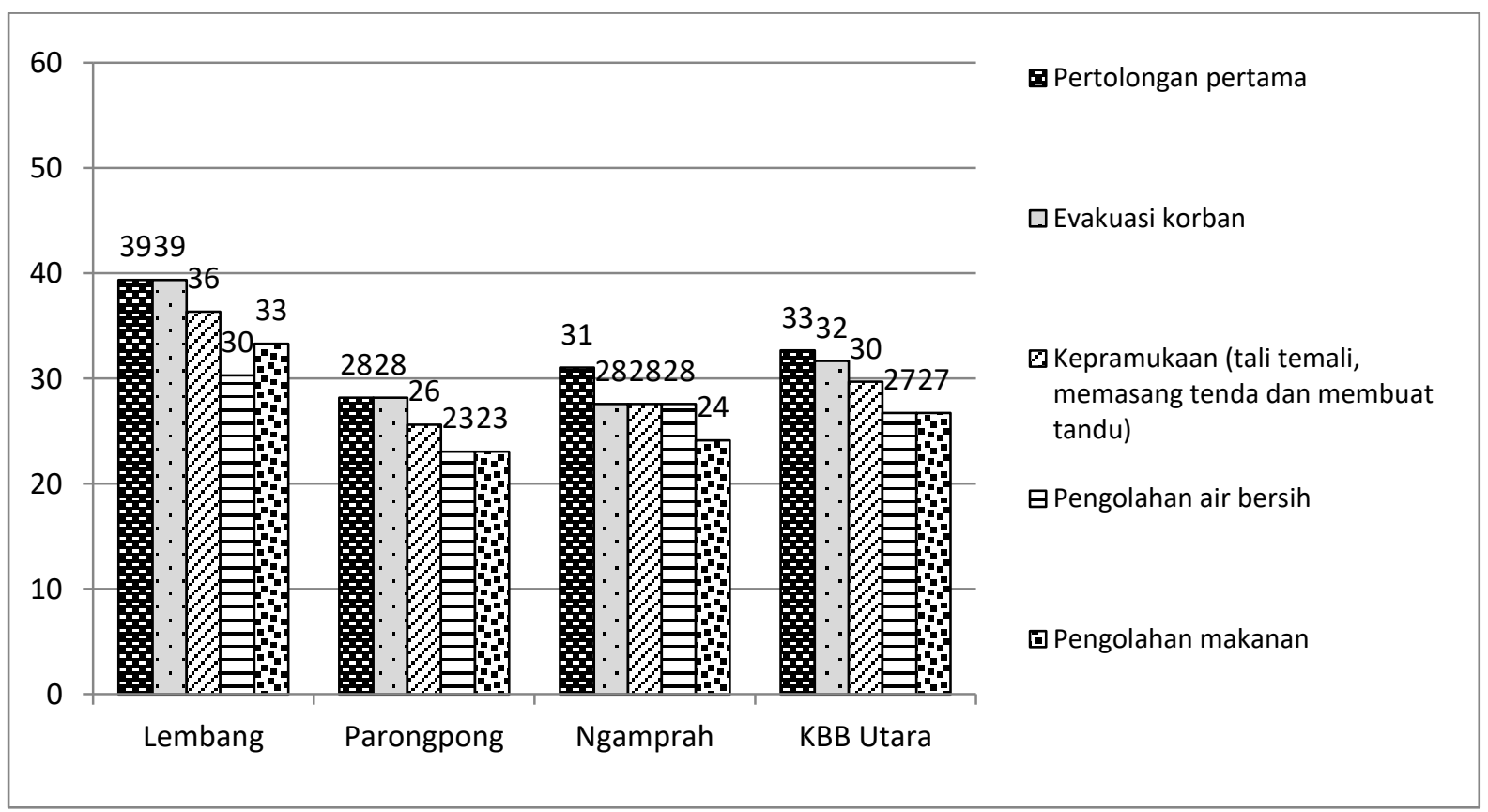

Gambar 10. Presentase Rumah Tangga yang Ikut Pelatihan Kesiapsiagaan Dalam Menghadapi Bencana

Sumber : Kajian Kesiapsiagaan masyarakat dalam mengantisipasi bencana alam (2006) 
Bila dikaji menurut jarak dari sumber gempa, anggota rumah tangga yang tinggal di Kecamatan Lembang banyak mengikuti pelatihan, seminar atau pertemuan yang berkaitan dengan kesiapsiagaan dibandingkan dengan kecamatan lain. Selain itu salah satu anggota rumah tangga di Kecamatan Lembang dan Ngamprah sering mengikuti pelatihan-pelatihan seperti pertolongan pertama, evakuasi korban dan pengolahan makanan dibandingkan dengan kecamatan Parongpong. Hal ini dapat dimengerti karena rumah tangga di Kecamatan Lembang paham bahwa daerahnya berisiko tinggi terhadap bencana gempa dari patahan lembang.

\section{Indeks Kesiapsiagaan Rumah Tangga}

Berdasarkan komposit dari ketiga parameter (pengetahuan, tanggap darurat dan mobilisasi sumbe daya), indeks kesiapsiagaan rumah tangga/individu di Kabupaten Bandung Barat bagian utara dikategorikan hampir siap dalam mengantisipasi bencana gempa (Gambar 11). Keadaan ini ditunjukkan dari nilai indeks yang hanya mencapai 58,88 dari nilai maksimum 100. Kehampirsiapan rumah tangga ini berlaku untuk semua lokasi kajian, yaitu Kecamatan Lembang dan Parongpong yang berada di jalur patahan Lembang serta Kecamatan Ngamprah yang dekat dengan patahan lembang. Nilai indeks tertinggi di Kecamatan Lembang dan terendah di Kecamatan Ngamprah.

Dari semua parameter, nilai indeks tertinggi adalah pengetahuan tentang kebencanaan 62,35 . Nilai indeks tersebut berarti penduduk mempunyai pengetahuan yang cukup memadai mengenai pengertian bencana, penyebab bencana, ciri-ciri gempa kuat dan tindakan yang harus dilakukan apabila terjadi bencana alam (gempa bumi). Besarnya nilai indeks ini kemungkinan terkait dengan kejadian gempa yang pernah mereka alami, yaitu bencana gempa bumi pada tahun 2011. Nilai indeks pengetahuan ini diikuti pula dengan tindak lanjut yang cukup memadai. Hal ini ditunjukkan dengan nilai indeks rencana tanggap darurat yang mencapai 60,43 . Besarnya nilai ini berarti bahwa rumah tangga di lokasi penelitian ini hampir siap dalam mengantisipasi bencana gempa bumi.

Indeks mobilisasi sumber daya di daerah penelitian masih sangat rendah 43,01, terendah dari semua nilai parameter. Kategori ini berarti termasuk dalam kurang siap. Rendahnya indeks ini disebarkan oleh rendahnya persentase rumah tangga dalam meningkatkan keterampilan dan investasi (tabungan, asuransi) yang berkaitan dengan kesiapsiagaan terhadap bencana gempa bumi.

Gambar 11. menunjukkan hampir kesiapsiagaan rumah tangga tercermin dari ketiga kecamatan, baik yang barada di jalur patahan maupun dan dekat dari sumber potensi gempa. Nilai indek kesiapsiagaan rumah tangga tertinggi terdapat di Kecamatan Lembang 61,38, disusul dengan Kecamatan Parongpong 59,15 dan Kecamatan Ngamprah 55,66, artinya rumah tangga di Kecamatan Lembang memiliki kesiapsiagaan lebih tinggi dibandingkan dengan Kecamatan Parongpong dan Ngamprah.

Peta indeks kesiapsiagaan rumah tangga di setiap lokasi penelitian sebagai bahan untuk melakukan evaluasi untuk menentukan prioritas lokasi yang akan mendapatkan upaya peningkatan indeks kesiapsiagaan (Susanto dan Putranto, 2016) terutama di daerah yang dekat dengan sumber gempa. Dari Gambar 11. daerah yang perlu mendapatkan prioritas peningkatan indeks kesiapsiagaan adalah semua lokasi kajian, dimulai dari Kecamatan Ngamprah, Parongpong dan Lembang. Prioritas peningkatan indeks kesiapsiagaan di Kecamatan Ngamprah adalah parameter mobilisasi sumber daya yang dikategori belum siap dan parameter pengetahuan dan rencana tanggap darurat yang dikategori hampir siap. Sementara prioritas peningkatan indeks kesiapsiagaan di Kecamatan Parongpong 
adalah parameter mobilisasi sumber daya yang dikategori kurang siap dan parameter rencana tanggap darurat sudah hampir siap, dan juga parameter pengetahuan sudah mencapai siap. Adapun prioritas peningkatan indeks kesiapsiagaan di Kecamatan Lembang yang diutamakan adalah parameter mobilisasi sumber daya yang dikategorikan belum siap, dan rencana tanggap darurat sudah hampir siap, dan juga pengetahuan sudah mencapai siap. Berdasarkan prioritas peningkatan indeks kesiapsiagaan di atas, maka ketika kecamatan tersebut menjadi prioritas utama kegiatan sosialisasi dan penerapan intervensi untuk meningkatkan ketahanan masyarakat, sehingga kemampuan rumah tangga dalam mengantisipasi bencana dapat ditingkatkan untuk mengurangi risiko bencana.

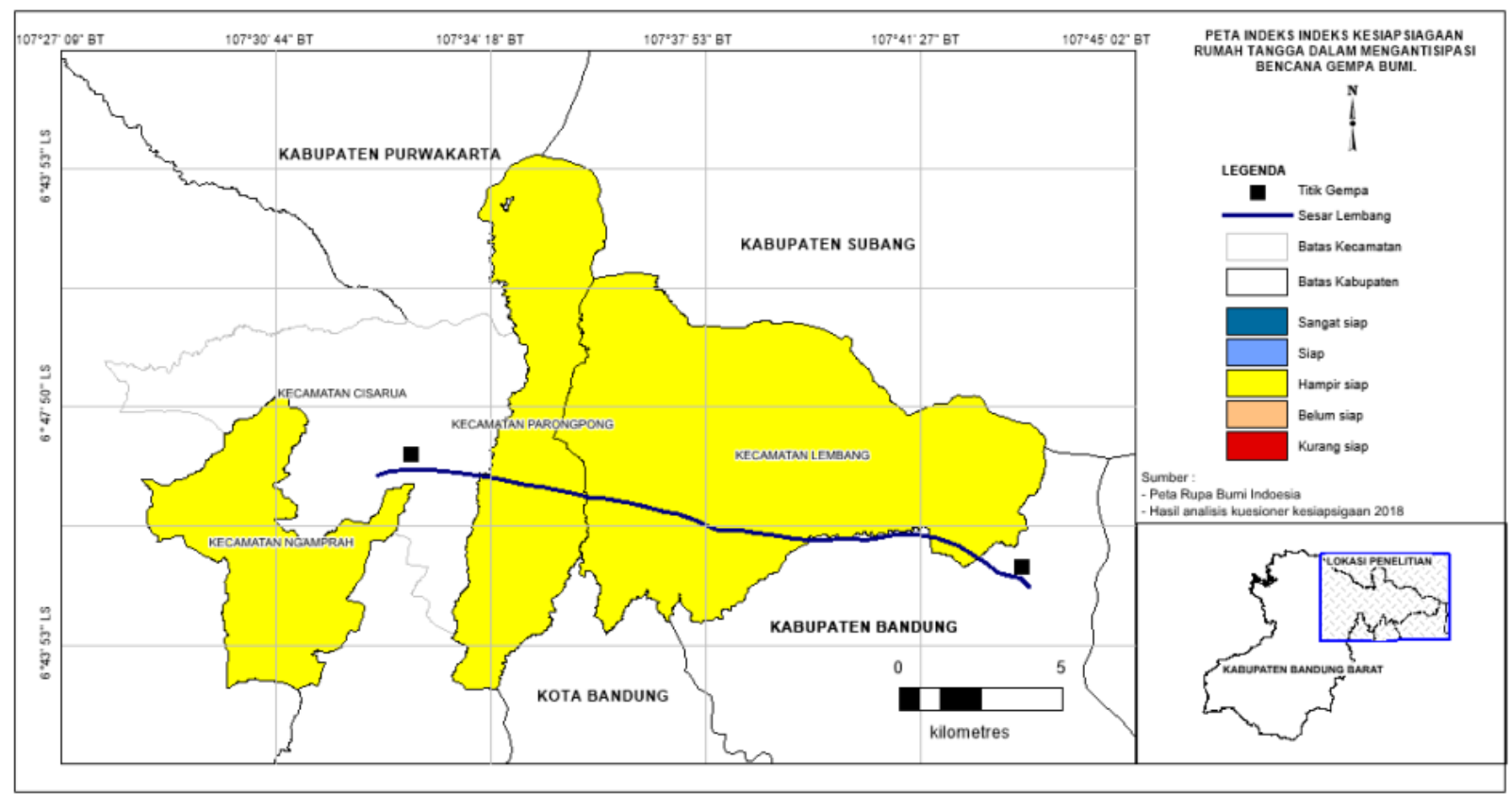

Gambar 11. Indeks Kesiapsiagaan Rumah Tangga Dalam Mengantisipasi Bencana Gempa Bumi

\section{KESIMPULAN}

Tingkat kesiapsiagaan rumah tangga/individu di daerah kawasan patahan Lembang dalam mengantisipasi gempa dikategorikan hampir siap (posisi ketiga) dibawah siap dan sangat siap. Kehampirsiapan ini ditunjang oleh parameter pengetahuan kesiapsiagaan dan rencana tanggap darurat yang sudah hampir siap, kecuali indeks mobilisasi sumber daya yang masih belum siap. Untuk itu semua lokasi kajian (Kecamatan Ngamprah, Parongpong, Lembang) perlu ditingkatkan indeks kesiapsiagaan melalui kegiatan sosialisasi dan penerapan intervensi, terutama meningkatkan kemampuan mobilisasi sumber daya, seperti peningkatkan keterampilan dan investasi (tabungan, asuransi) yang berkaitan dengan kesiapsiagaan terhadap bencana gempa bumi. Dengan sosialisasi ini diharapkan dapat meningkatkan ketahanan rumah tangga sehingga selalu siap siaga dalam mengantisipasi bencana. Salah satu kegiatan sosialisasi melalui peningkatkan pengetahuan, keterampilan dan melakukan berbagai upaya untuk mengurangi risiko bencana, terutama korban jiwa. Upaya meningkatkan kesiapsiagaan melalui sosialisasi perlu melibatkan berbagai lembaga, baik pemerintah, LSM dan masyarakat secara periodik atau terus-menurus agar rumah tangga/individu semakin siap dalam mengantisipasi bencana. 


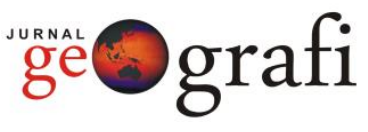

UCAPAN TERIMA KASIH

Ucapkan terima kasih pertama kepada Kepala Pusat Penelitian Geoteknologi-LIPI, yang telah memberikan kesempatan kepada penulis untuk terlibat dalam kegiatan penelitian Prioritas Nasional Penilaian Risiko Bencana tahun 2018. Penulis juga mengucapkan terima kasih kepada Kepala Desa Cibodas, Kepala Desa Langensari, Kepala Desa Cihanjuang Rahayu, Sekretaris Desa Ngamprah dan Kepala Desa Cilame yang telah banyak memberikan informasi tentang kesiapan masyarakat dalam menghadapi bencana, selama penelitian ini dilakukan. Selanjutnya ucapan terima kasih ditujukan kepada rekan-rekan peneliti Puslit Geoteknologi-LIPI yang telah membantu hingga terselenggaranya penelitian ini.

\section{DAFTAR PUSTAKA}

Badan Nasional Penanggulangan Bencana. (2017). Buku saku tanggap tangkas tangguh menghadapi bencana. BNPB.

Badan Pusat Statistik. (2017). Kabupaten Bandung Barat dalam Angka 2017, BPS Kabupaten Bandung Barat.

Badan Meteorologi, Klimatologi, dan Geofisika (2017). Penjelasan BMKG Terkait Hasil Kajian Sesar Lembang yang Berpotensi Memicu Gempa Berkekuatan $\mathrm{M}=6.8$. Diunduh: http://www.bmkg.go.id/press-rele ase $/ ?$ p $=$ penjelasan-bmkg-terkait-ha sil-kajian-sesar-lembang-yang-ber potensi-memicu-gempa-berkekua tan-m6-8\&lang=ID. [10 September 2018].

Daryono, M. R. (2016). Paleoseismologi Tropis Indonesia (Dengan Studi Kasus di Sesar Sumatra, Sesar Palukoro-Matano, dan Sesar Lembang). Disertasi Program Doktor, Institut Teknologi Bandung.
Hidayati, D., Permana, H., Pribadi, K., Ismail, F., Meyer, K., Widayatun, Handayani, T., Bustami, DA., Daliyo, Fitranita, Nagib Laila, Ngadi, Kumoro Y., Rafliani I., Argo T. (2006). Kajian kesiapsiagaan masyarakat dalam mengantisipasi bencana gempa bumi dan tsunami. LIPI - UNESCO/ISDR.

Hidayati, D. (2008). Kesiapsiagaan masyarakat : paradigma baru pengelolaan bencana alam di Indoensia. Jurnal Kependudukan Indonesia, Vol. III, No. 1, 2008.

Hidayati, D., Ngadi, S.S Purwaningsih, and M. Soekarno. (2008). Kesiapsiagaan Masyarakat dalam Mengantisipasi Bencana Alam di Kabupalen Cilacap. LIPI Press. ISBN: 978-979-799-287-3.

Hidayati D., Widayatun, Hartana, P., Triyono. Kusumawati T. (2011). Panduan mengukur kesiapsiagaan masyarakat dan komunitas sekolah. LIPI. ISBN : 978-979-799-677-2.

Maipark. (2015). Terlelap didamainya sesar Lembang. Waspada Edisi 23, Juli-Desember 2015.

Meilano I., Abidin, H.Z., Abidin, Andreas H., Gumilar I., Sarsito D., Hanifa R., Rino, Harjono H., Kato T. (2012). Slip rate estimation of the Lembang fault West Java from from geodetic observation. Journal of Disaster Research Vol. 7, No.1, 2012.

Nagib, L., D. Asiati, A. Latifa, dan Mujiyani. (2007). Kesiapsiagaan Masyarakat dalam Mengantisipasi Bencana Alam di Kabupaten Padang Pariaman. Pusat Penelitian Oseanografi - LIPI.

Silitonga, P.H. (1973). Peta Geologi Lembar Bandung skala 1:100.000, 
Pusat Penelitian dan Pengembangan Geologi.

Sungkawa, D. (2016). Dampak Gempa Bumi terhadap lingkungan hidup, Diunduh

http://download.portalgaruda.org/ article.php?article $=436514 \& \mathrm{val}=8426$ \&title=DAMPAK \%20GEMPA \%20B UMI\%20TERHADAP\%20LINGKUN GAN\%20HIDUP. [25 Juni 2018].

Sulaeman C., dan Hidayati, S. (2011). Gempa Bumi Bandung 22 Juli 2011. Jurnal Lingkungan dan Bencana Geologi. Vol. 2 No 3, Desember 2011: 185-190. ISSN: 2502-8804.

Susanto, N., dan Putranto, T.T. (2016). Analisis Level Kesiapan Warga Menghadapi Potensi Bencana Longsor Kota Semarang. TEKNIK, p-ISSN 0852-1697, e-ISSN: 24609919.

doi:10.14710/teknik.v37n2.9815.

Diunduh:

https://www.researchgate.net/pub lication/313317719_Analisis_Level_ Kesiapan_Warga_Menghadapi_Pote nsi_Bencana_Longsor_Kota_Semara ng. [5 September 2018].

Triyono, Kurniah, Andriana, N., Kusumawati, T., Hardianto, N. (2014). Pedoman Kesiapsiagaan Menghadapi Gempa Bumi dan Tsunami. BNPB-LIPI.

Sutton, J., and Tierney, K. (2006). Disaster Preparedness: Concepts, Guindance and Research. Colorado: University of Colorado.

Undang-undang No 24 tahun 2017 tentang Penanggulangan Bencana.

Yulianto, E. (2011). Understanding the Earthquake Threat to Bandung from the Lembang fault, AustraliaIndonesia Facility for Disaster
Reduction (AIFDR) Project Report, Jakarta, 22 pp.

Yulianto, E. (2012). Di Langit Pasir Halang Bulan Temaram.

Diunduh :

http://wiki.openstreetmap.org/w/i mages/2/2e/Diseminasi_PRB_Sesar LLembang.pdf. [23 Juli 2018]. 